\title{
Pengaruh Tomat Sambung Pada Intensitas Penyakit Layu Bakteri (Ralstonia solanacearum), Komponen Hasil Produksi, dan Kualitas Buah
}

\section{(The Effect of Tomato Grafted on Diseases Intensity of Ralstonia solanacearum, Component of Yield, and Fruit Quality)}

\author{
Lisa Navitasari ${ }^{1,2 \star}$, Tri Joko $^{1}$, Rudi Hari Murti ${ }^{3}$, Triwidodo Arwiyanto ${ }^{1}$ \\ (Diterima Juni 2020/Disetujui Juni 2021)
}

\begin{abstract}
ABSTRAK
Ralstonia solanacearum (Smith) merupakan salah satu patogen tular tanah yang menyebabkan penyakit layu bakteri pada tanaman tomat dan $\boldsymbol{R}$. solanacearum tersebut sulit dikendalikan karena mampu bertahan lama di dalam tanah serta memiliki kisaran inang yang luas. Salah satu alternatif pengendalian penyakit layu bakteri sekaligus meningkatkan hasil tanaman adalah penyambungan dengan kombinasi penggunaan varietas tomat tahan sebagai batang bawah dan varietas tomat berproduksi tinggi sebagai batang atas. Pengendalian $R$. solanacearum dengan penyambungan telah banyak dilakukan dan dilaporkan. Akan tetapi, pengaruh penyambungan dengan batang bawah tahan (Amelia dan H7996) dan varietas tomat berproduksi tinggi (Servo) dengan infestasi $R$. solanacearum dan tanpa infestasi $\boldsymbol{R}$. solanacearum pada intensitas penyakit layu bakteri, komponen hasil produksi, dan kualitas buah belum banyak dilaporkan. Penelitian ini bertujuan untuk melihat pengaruh penyambungan yang terinfestasi $R$. solanacearum pada intensitas penyakit, komponen hasil tanaman, dan kualitas buah. Hasil penelitian menunjukkan bahwa intensitas penyakit layu bakteri pada tomat sambung tidak berbeda nyata dibandingkan dengan batang bawah tahan, namun berbeda nyata dibandingkan dengan batang atas. Infestasi $R$. solanacearum pada tomat sambung mampu menurunkan produktivitas tanaman yang mengakibatkan komponen hasil produksi tanaman tomat sambung menjadi rendah. Selain itu, infestasi $R$. solanacearum juga menurunkan kualitas buah, yaitu diameter dan kekerasan buah. Akan tetapi, infestasi $R$. solanacearum tidak berpengaruh pada nilai ( ${ }^{\circ}$ brix) total padatan terlarut (TTS) buah. Nilai ( ${ }^{\circ}$ brix) TTS pada tomat sambung menunjukkan nilai yang lebih tinggi dibandingkan dengan batang bawah tahan pada kondisi lahan terinfestasi dan lahan tidak terinfestasi $R$. solanacearum.
\end{abstract}

Kata kunci: kualitas buah, produksi, Ralstonia solanacearum, tomat sambung

\section{ABSTRACT}

Ralstonia solanacearum (Smith) is one of soil borne pathogens causes bacterial wilt diseases and $R$. solanacearum is difficult to control because it has a long survival in the soil and have many hosts alternatives. One alternative to control $R$. solanacearum and to increase productivity is by using grating with combination of resistant varieties of tomato as a rootstock and high production varieties of tomato as a scion. Several studies on grafting to suppress $R$. solanacearum were reported. However, study on grafting with combination between resistant tomato varieties (Amelia H7996) and high-production tomato varieties with $R$. solanacearum infestation and without $R$. solanacearum infestation on the component of yield and fruit quality is limited. The study aims to analyze the effect of grafting with $R$. solanacearum infestation to the intensity of bacterial wilt disease, component of yield, and fruit quality with $R$. solanacearum infestation and without $R$. solanacearum infestation. The result indicated that the intensity of bacterial wilt disease on grafted tomato did not significantly different from resistant rootstock but significantly different from scion. Infestation of $R$. solanacearum on grafted tomato can decreased the plant productivity that decreased the component of yield on grafted tomato. $R$. solanacearum infestation also decreased the fruit quality on diameters and fruit firmness. Nevertheless, $R$. solanacearum did not affect the Total soluble solid/TSS ( $\left.{ }^{\circ} \mathrm{Brix}\right)$. TSS on grafted tomato indicated that the value is taller than rootstock in the field with $R$. solanacearum infestation and in the field without $R$. solanacearum infestation.

Keywords: fruit quality, productivity, Ras/tonia solanacearum, tomato grafted

1 Departemen Proteksi Tanaman, Fakultas Pertanian, Universitas Gadjah Mada, Jalan Flora No.1. Bulaksumur, Sleman, Yogyakarta, 55281

2 Politeknik Pembangunan Pertanian Malang, Kementerian Pertanian, JI. DR. Cipto No.144a, Sengkkrajan, Bedali, Kec. Lawang, Malang, 65215

${ }^{3}$ Departemen Agronomi, Fakultas Pertanian, Universitas Gadjah Mada, Jalan Flora No.1. Bulaksumur, Sleman, Yogyakarta, 55281

* Penulis Korespondensi: Email: lissa.nav@gmail.com

\section{PENDAHULUAN}

Ralstonia solanacearum (Smith) merupakan salah satu patogen tular tanah yang menyebabkan penyakit layu bakteri pada tanaman tomat. Penyakit layu bakteri yang disebabkan oleh $R$. solanacearum menyebabkan kehilangan hasil hingga 100\% (Davis et al. 2008). $R$. solanacearum beradaptasi dengan baik di dalam tanah dan mampu bertahan lama di rizosfer serta memiliki 
kisaran inang yang luas (Kalpage \& De Costa 2014). Hal ini yang mengakibatkan $R$. solanacearum penyebab penyakit layu bakteri yang semakin sulit dikendalikan. Salah satu alternatif pengendalian penyakit layu bakteri yang dapat dilakukan adalah penyambungan dengan menggunakan batang bawah tahan. Penyambungan dengan batang bawah tahan secara signifikan mampu mengurangi kejadian penyakit layu bakteri di lapangan, memperbaiki ketahanan tanaman terhadap patogen tular tanah, dan meningkatkan ketahanan tanaman (Louws et al. 2010; Arwiyanto et al. 2015). Suchoff et al. (2014) juga melaporkan adanya kejadian penyakit layu bakteri pada tomat sambung yang lebih rendah dibandingkan dengan tomat tanpa sambung.

Penyambungan dengan menggunakan varietas tomat tahan sebagai batang bawah mampu menurunkan penyakit layu bakteri, namun belum tentu dapat meningkatkan produksi dan kualitas buah. Hal ini dikarenakan hasil produksi dan kualitas buah di dalam penyambungan dipengaruhi oleh varietas tomat yang digunakan sebagai batang atas. Hal ini sejalan dengan penelitian Davis et al. (2008) yang melaporkan bahwa batang atas di penyambungan memengaruhi ukuran, hasil produksi, dan kualitas buah pada tomat sambung. Penyambungan dengan kombinasi antara batang bawah tahan dan batang atas yang memiliki sifat agronomi baik menjadi kombinasi terbaik dalam menekan penyakit layu bakteri sekaligus meningkatkan hasil produksi. Hal ini sejalan dengan hasil penelitian Hariyadi et al. (2012) yang melaporkan bahwa penyambungan dengan pemilihan kombinasi antara batang bawah dan batang atas berpotensi hasil tinggi memberikan banyak keunggulan dan keuntungan.

Varietas tomat tahan terhadap $R$. solanacearum yang dapat digunakan sebagai batang bawah di antaranya adalah varietas tomat $\mathrm{H} 7996$ dan Amelia. Tomat varietas $\mathrm{H} 7996$ merupakan varietas yang tahan terhadap $R$. solanacearum yang direkomendasikan oleh Asian Vegetable Research Development Center (AVRDC) karena memiliki kandungan senyawa fenol yang dapat menghambat $R$. solanacearum (AVRDC, 2013), sedangkan tomat varietas Amelia adalah varietas lokal Indonesia yang memiliki ketahanan terhadap penyakit layu bakteri yang disebabkan oleh $R$. solanacearum (Laeshita \& Arwiyanto 2017). Kombinasi penyambungan antara varietas tomat tahan sebagai batang bawah merupakan metode yang efektif dalam menurunkan kejadian penyakit layu bakteri (McAvoy et al. 2012). Akan tetapi, penyambungan dengan kombinasi varietas tomat tahan (Amelia dan $\mathrm{H} 7996)$ dengan varietas tomat berproduksi tinggi (Servo) yang terinfestasi $R$. solanacearum memengaruhi intensitas penyakit layu bakteri, komponen hasil produksi, dan kualitas buah belum pernah dilaporkan secara detail. Penelitian ini bertujuan untuk melihat pengaruh penyambungan pada intensitas penyakit layu bakteri, komponen hasil produksi tomat, dan kualitas buah pada tanaman yang terinfestasi $R$. solanacearum dan tanpa infestasi $R$. solanacearum.

\section{METODE PENELITIAN}

\section{Lokasi dan Waktu Penelitian}

Penelitian dilaksanakan pada Januari-Juli 2020 di Laboratorium Bakteri, Program Studi Proteksi Tanaman, Fakultas Pertanian, Universitas Gajah Mada. Penanaman tomat sambung dilakukan di Lahan Percobaan milik Politeknik Pembangunan Pertanian Yogyakarta-Magelang (Kementerian Pertanian) seluas $200 \mathrm{~m}^{2}$.

\section{Persiapan Inokulum $\boldsymbol{R}$. solanacearum}

Isolat $R$. solanacearum diambil dari rhizosfer tanaman tomat yang menunjukkan gejala penyakit layu bakteri di Sleman, Yogyakarta, Indonesia. Isolat $R$. solanacearum kemudian ditambahkan akuades steril sebanyak $10 \mathrm{ml}$. Suspensi $R$. solanacearum tersebut diukur OD=0,1 (Optical Density) dengan menggunakan Spektrofotometer UV-UVIS Genesys 10S pada panjang gelombang $600 \mathrm{nM}$. Suspensi $R$. solanacearum yang memiliki OD 0,1 digunakan untuk infestasi $R$. solanacearum pada tanaman tomat sambung dan tanpa sambung (kontrol).

\section{Desain Percobaan Penyambungan dan Perlakuan}

Penyambungan dilakukan dengan menggunakan kombinasi antara tomat varietas tahan Amelia (Deskripsi varietas; Laeshita dan Arwiyanto, 2017) dan H7996 (AVRDC 2013) dengan tomat varietas berproduksi tinggi (Servo) (Deskripsi varietas Easwest, 2019). Varietas tomat tahan digunakan sebagai batang bawah dan tomat varietas berproduksi tinggi digunakan sebagai batang atas. Rancangan percobaan yang digunakan adalah randomized completely block design dengan 5 perlakuan, yaitu penyambungan (GrfAmls dan GrH7996S) varietas tomat tahan (Amelia, H7996), dan varietas tomat berproduksi tinggi (Servo) yang diinfestasi $R$. solanacearum dan tanpa infestasi $R$. solanacearum dengan ulangan sebanyak 4 kali. Masing-masing perlakuan terdiri atas 10 tanaman sehingga total tanaman yang digunakan sebanyak 360 tanaman (Gambar 1).

\section{Penyambungan dan Penanaman Tomat Sambung di Lahan}

Penyambungan dilakukan dengan menggunakan metode tube grafting. Penyambungan dilakukan ketika tanaman memiliki ukuran antara batang bawah dan batang atas sama, yaitu 21 hari setelah semai. Tanaman batang bawah dan batang atas masingmasing dipotong dengan kemiringan $45^{\circ}$ kemudian tanaman disatukan dengan menggunakan perantara karet pentil yang telah dipotong dengan kemiringan $45^{\circ}$ sepanjang $1 \mathrm{~cm}$. Sambungan kemudian dipindahkan ke dalam healing chamber selama 10 hari dengan 
Blok 1

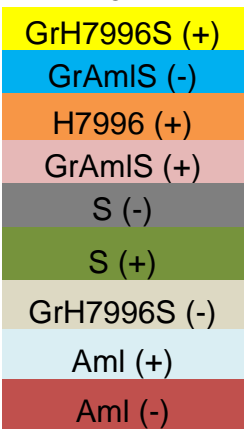

Blok 2

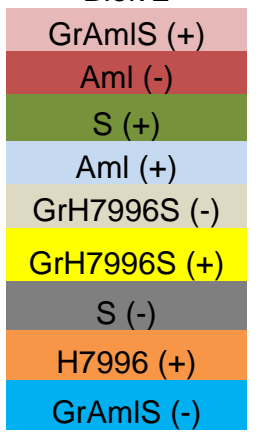

Blok 3

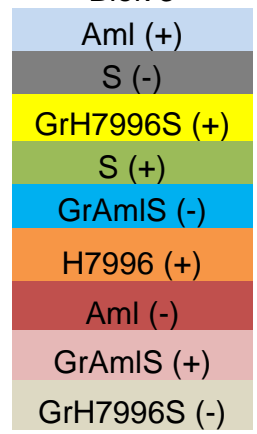

Blok 4

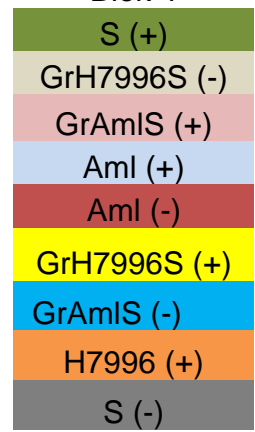

Gambar 1 Denah percobaan penelitian dengan metode Randomized Completely Block Design (RCBD). GrH7996, yaitu tomat sambung H7996+Servo, GrAmIS, yaitu tomat sambung Amelia+Servo, Aml, yaitu Amelia, S, yaitu Servo, $(+) R$. solanacearum, (-) tanpa infestasi $R$. solanacearum.

temperatur dan kelembapan relatif di dalam healing chamber masing-masing sebesar $22-25^{\circ} \mathrm{C}$ dan 90-95\% yang diukur menggunakan alat thermohygrometer. Setelah 10 hari di dalam healing chamber, tomat sambung, varietas tomat tahan, dan varietas tomat berproduksi tinggi dipotong akarnya dan dipindah tanam ke lahan yang sudah diberi pupuk dan mulsa perak hitam. Tanaman ditanam dengan jarak tanam $50 \mathrm{~cm}$ x $60 \mathrm{~cm}$. Infestasi $R$. solanacaearum diberikan dengan cara menyiramkan suspensi $R$. solanacearum sebanyak $30 \mathrm{ml}$ di dekat akar tanaman tomat sambung, varietas tomat tahan, dan varietas tomat berproduksi tinggi yang telah ditanam di lahan.

\section{Pengamatan pada Intensitas Penyakit Layu Bakteri}

Penilaian perkembangan intensitas penyakit layu bakteri ditentukan dengan intensitas penyakit (\%) dengan sistem skala skor sebagai berikut: Skor $0=$ semua daun sehat, skor $1=1 \leq \mathrm{IP}<10 \%$ daun layu, skor $2=10 \leq \mathrm{IP}<30 \%$ daun layu, skor $3=30 \leq \mathrm{IP}<60 \%$ daun layu, skor $4=60 \leq I P<100 \%$ daun layu, dan skor $5=100 \%$ daun layu (tanaman mati) (Arwiyanto \& Hartana 1999). Intensitas penyakit dihitung dengan rumus:

$$
\text { Intensitas Penyakit (IP) }=\frac{\sum_{i=I}^{k} k x n k}{N x V} \times 100 \%
$$

\section{Keterangan:}

$\mathrm{Nk}=$ Jumlah tanaman yang terserang penyakit dengan skala $\mathrm{k}(\mathrm{k}=0,1,2,3,4,5)$

$\mathrm{N}$ = Jumlah tanaman yang diamati

$\mathrm{Z} \quad$ = Skala penyakit tertinggi

\section{Pengamatan pada Komponen Hasil Produksi dan Kualitas Buah}

Pengamatan pada komponen hasil produksi meliputi jumlah buah/tanaman, bobot buah/tanaman (g), bobot buah (g), dan diameter buah (cm), sedangkan pengamatan pada kualitas buah meliputi kekerasan buah dan total padatan terlarut ( ${ }^{\circ}$ Brix). Diameter buah diukur dengan menggunakan jangka sorong, sedangkan kekerasan buah diukur dengan alat Penetrometer. Total padatan terlarut diukur dengan mengambil sari buah tomat yang kemudian diukur menggunakan Hand Refractometer.

Produktivitas tomat sambung, varietas tomat tahan, dan varietas tomat rentan yang ditanam dengan infestasi $R$. solanaceaum dan tanpa infestasi $R$. solanacearum dihitung dengan mengkonversi populasi tanaman/ha dibagi jumlah tanaman sampel dikalikan jumlah bobot buah tanaman sampel.

\section{Analisis Data}

Data produktivitas, komponen hasil tanaman, kualitas buah pada tomat sambung, varietas tomat tahan, dan varietas tomat berproduksi tinggi yang terinfestasi dan tanpa infestasi $R$. solanacearum dianalisis dengan menggunakan software SPSS 21. Hasil yang menunjukkan perbedaan nyata diuji lanjut dengan uji Duncan alpha 5\%. Perbandingan antara perlakuan tomat sambung, varietas tomat tahan, dan varietas tomat berproduksi tinggi yang terinfestasi $R$. solanacearum dan tanpa infestasi $R$. solanacearum dianalisis dengan uji T alpha $5 \%$.

\section{HASIL DAN PEMBAHASAN}

\section{Penyambungan dan Intensitas Penyakit Layu Bakteri}

Penyambungan tanaman tomat menggunakan metode tube (splice) dengan perantara sambungan karet pentil memiliki tingkat keberhasilan $75 \%$ untuk tingkat pemula. Hal ini terlihat dari sebanyak 600 tomat yang disambung, tomat yang memiliki sambungan berhasil sebanyak 450 tanaman. Penyambungan dengan penggunaan batang bawah tahan terhadap $R$. solanacearum dapat menjadi alternatif untuk menekan penyakit layu bakteri. Hal ini ditunjukkan oleh jumlah tanaman sehat (tidak layu) pada varietas tomat tahan (Amelia dan H7996) terhadap $R$. solanacearum dibandingkan dengan tanaman berproduksi tinggi (Servo) (Gambar 2).

Jumlah tanaman yang mati pada varietas tomat berproduksi tinggi (Servo) dibandingkan dengan varietas tomat tahan dengan infestasi $R$. solanacearum menunjukkan bahwa tanaman tomat berproduksi tinggi 
merupakan tanaman yang rentan terhadap $R$. solanacearum. Hal ini diduga karena gen ketahanan pada tanaman berbanding terbalik dengan gen produksi. Rendahnya varietas tomat tahan yang memiliki jumlah tanaman layu/ mati berpengaruh pada jumlah tanaman yang layu/mati pada tanaman tomat sambung (Gambar 3). Hal ini menunjukkan bahwa penggunaan varietas tomat tahan mampu menekan penyakit layu bakteri. Hal ini sejalan dengan pendapat Poudel et al. (2019) yang menyatakan bahwa batang bawah di penyambungan memengaruhi ketahanan terhadap serangan patogen. Arwiyanto et al. (2015) melaporkan bahwa penggunaan varietas tahan $\mathrm{H} 7996$ mampu menekan penyakit layu bakteri.

Perbedaan jumlah tanaman yang sehat dan layu pada tanaman yang diinfestasi $R$. solanacearum dipengaruhi oleh tingkat ketahanan tanaman terhadap serangan patogen. Varietas tomat tahan (Amelia dan H7996) menunjukkan intensitas penyakit layu bakteri yang lebih rendah dibandingkan tomat sambung dan varietas tomat berproduksi tinggi (Servo). Tomat sambung memiliki intensitas penyakit layu bakteri yang tidak berbeda nyata dibandingkan dengan varietas tomat tahan, namun berbeda nyata dibandingkan dengan varietas tomat berproduksi tinggi (Servo) (Tabel 1).
Tomat sambung menunjukkan intensitas penyakit layu bakteri yang lebih tinggi dibandingkan dengan varietas tomat tahan. Hal ini diduga karena varietas tomat berproduksi tinggi bersifat rentan terhadap $R$. solanacearum yang memengaruhi level ketahanan tanaman dan tomat sambung diduga memiliki kelimpahan $R$. solanacearum yang lebih tinggi dibandingkan dengan varietas tomat tahan sebagai batang bawah. Hal ini sejalan dengan pengamatan Navitasari et al. (2020) yang melaporkan bahwa tomat sambung memiliki kelimpahan $R$. solanacearum yang lebih tinggi dibandingkan dengan tomat tanpa sambung.

Tabel 1 Intensitas penyakit layu bakteri ( $R$. solanacearum) pada tanaman tomat

\begin{tabular}{lc}
\hline \multicolumn{1}{c}{ Group } & Intensitas penyakit layu bakteri (\%) \\
\hline Amelia & $21.87 \mathrm{a}$ \\
H7996 & $30.37 \mathrm{a}$ \\
Servo & $69.37 \mathrm{~b}$ \\
GrftAmIS & $38.00 \mathrm{a}$ \\
GrH7996S & $40.69 \mathrm{a}$
\end{tabular}

Keterangan: Alpha $=.05$. Kontrol (Amelia, H7996, dan Servo), Penyambungan (GrftAmlS dan GrH7996S). Angka yang diikuti huruf yang sama pada kolom yang sama menunjukkan hasil yang tidak berbeda nyata

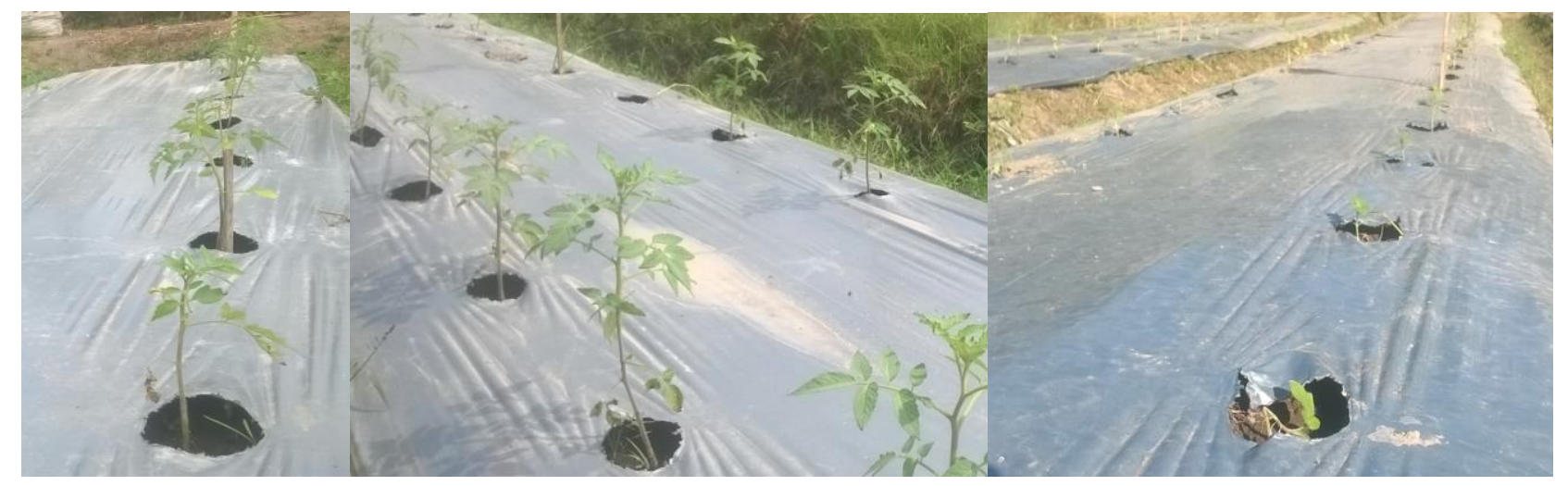

Gambar 2 Varietas tomat tahan (H7996 dan Amelia) yang diinfestasi $R$. solanacearum menunjukkan tanaman sehat, sedangkan varietas tomat berproduksi tinggi (Servo) menunjukkan banyak tanaman yang layu dan mati.

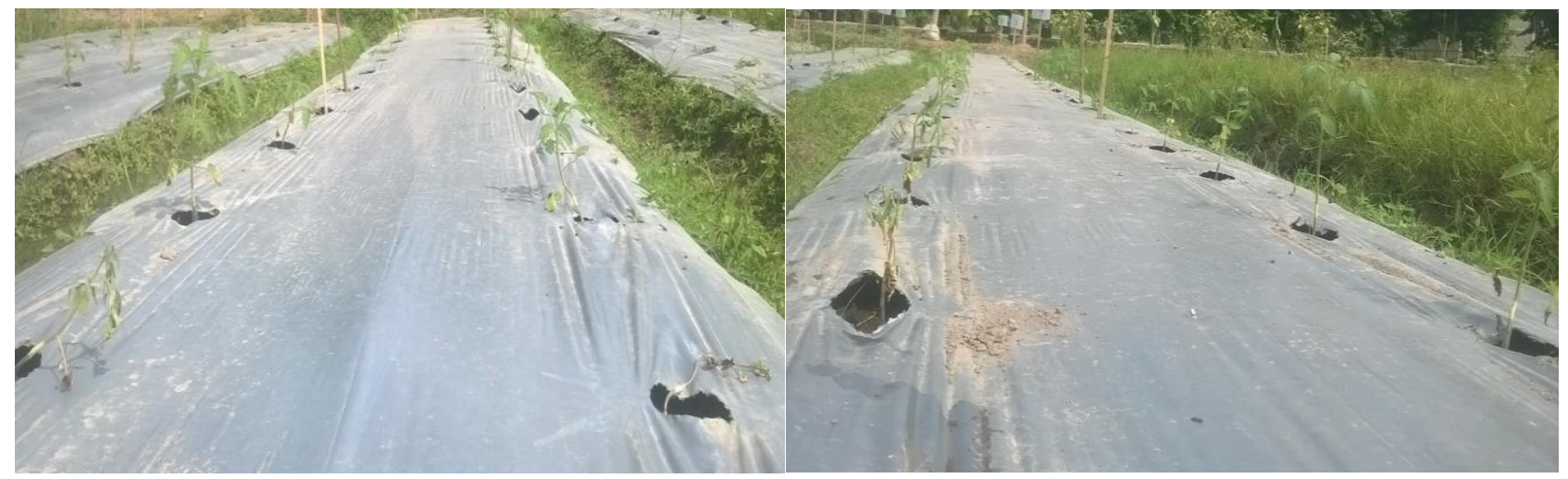

Gambar 3 Tomat sambung yang menunjukkan gejala penyakit layu bakteri dan tidak bergejala penyakit layu bakteri (Sehat). 
Pengaruh $R$. solanacearum pada intensitas penyakit layu bakteri pada produktivitas tanaman, komponen hasil produksi, dan kualitas buah

Infestasi $R$. solanacearum mengakibatkan adanya perbedaan persentase intensitas penyakit layu bakteri antara tomat sambung, varietas tomat tahan, dan varietas tomat berproduksi tinggi (Tabel 2).

Tomat varietas berproduksi tinggi (Servo) bersifat rentan terhadap $R$. solanacearum yang menunjukkan intensitas penyakit layu bakteri yang tinggi dan menurunkan produktivitas tanaman yang tinggi. Tomat sambung dengan penggunaan varietas tomat tahan sebagai batang bawah menunjukkan adanya penurunan produktivitas yang berbeda nyata dibandingkan dengan varietas tomat tahan. Hal ini diduga karena penggunaan varietas tomat berproduksi tinggi yang rentan sebagai batang atas memengaruhi ketahanan tanaman terhadap $R$. solanacearum. Hal ini sejalan dengan pengamatan Navitasari et al. (2020) yang melaporkan bahwa tomat sambung menunjukkan adanya perpaduan level ketahanan antara varietas tanaman yang digunakan sebagai batang bawah dan batang atas.

Tomat sambung (GrH7996S) menunjukkan adanya penurunan produktivitas yang tidak berbeda nyata dibandingkan dengan varietas tomat berproduksi tinggi yang rentan terhadap $R$. solanacearum (Servo). Hal ini diduga bahwa varietas tomat $\mathrm{H} 7996$ mengalami perubahan level ketahanan dari tahan menjadi rentan. $\mathrm{Hal}$ ini sejalan dengan pernyataan Navitasari et al. (2020) yang melaporkan bahwa varietas H7996 mengalami perubahan level ketahanan dari resistan menjadi rentan. Hanson et al. (2015) juga melaporkan tomat yang tahan terhadap $R$. solanacearum di Malaysia dan Taiwan ketika ditanam di Filipina dan Indonesia menjadi rentan terhadap $R$. solanacearum.
Perubahan level ketahanan terhadap R. solanacearum berpengaruh pada penurunan komponen hasil produksi yang lebih rendah (Tabel 3).

Komponen hasil tanaman pada tomat sambung yang terinfestasi $R$. solanacearum menunjukkan bahwa jumlah buah/tanaman, bobot buah/tanaman, dan bobot buah tidak berbeda nyata dibandingkan dengan batang atas (Servo). Hal ini diduga karena komponen hasil produksi tomat sambung dipengaruhi oleh varietas tomat yang digunakan sebagai batang atas. Hal ini sejalan dengan laporan Davis et al. (2008) yang menyatakan bahwa batang atas pada penyambungan memengaruhi ukuran, hasil, dan kualitas buah pada tomat sambung. Sebaliknya tomat tanpa sambung (varietas tomat tahan dan varietas tomat berproduksi tinggi), komponen hasil produksi dipengaruhi oleh karakteristik genetika varietas tersebut. Akan tetapi, tomat sambung yang tidak terinfestasi $R$. solanacearum menunjukkan bahwa komponen hasil produksi tidak berbeda nyata dibandingkan dengan batang atas dan batang bawah.

Perlakuan tanpa infestasi $R$. solanacearum memberikan pengaruh pada tomat sambung yang memiliki jumlah buah/tanaman dan bobot buah/tanaman yang lebih tinggi dibandingkan dengan batang bawah dan batang atas. Hal ini diduga bahwa tomat sambung memiliki kelimpahan unsur $\mathrm{N}$ dan $\mathrm{P}$ yang tinggi. Hal ini sejalan dengan pernyatan Schwarz et al. (2012) dan Nie et al. (2010) yang melaporkan bahwa tomat sambung memiliki penyerapan $\mathrm{N}$ dan $\mathrm{P}$ yang lebih tinggi dibandingkan dengan tomat tanpa sambung. Akan tetapi, infestasi $R$. solanacearum mengakibatkan adanya perbedaan yang nyata pada komponen hasil produksi. Hal ini dapat terlihat dari hasil uji T yang memiliki nilai sig $<0,05 \%$, artinya bahwa ada perbedaan yang nyata antara infestasi $R$.

Tabel 2 Produktivitas dan penurunan produktivitas pada tomat sambung yang diinfestasi dengan $R$. solanacearum dan tanpa infestasi $R$. solanacearum

\begin{tabular}{|c|c|c|c|}
\hline \multirow[b]{2}{*}{ Grup } & \multicolumn{2}{|c|}{ Produktivitas (ton/ha) } & \multirow{2}{*}{$\begin{array}{l}\text { Penurunan produktivitas oleh infeksi } \\
\text { R. solanacearum (\%) }\end{array}$} \\
\hline & Infeksi $R$. solanacearum & $\begin{array}{c}\text { Tanpa infeksi } R \text {. } \\
\text { solanacearum }\end{array}$ & \\
\hline Amelia & $15,60 \mathrm{c}$ & $18,82 a b$ & $17,11 \mathrm{~b}$ \\
\hline GrftAmIS & $11,25 b$ & $18,05 a b$ & $37,67 c$ \\
\hline $\mathrm{H} 7996$ & $15,31 \mathrm{c}$ & $17,20 \mathrm{a}$ & $10,99 a$ \\
\hline GrH7996S & $7,70 a b$ & $23,52 c$ & $67,26 \mathrm{~d}$ \\
\hline Servo & $5,09 a$ & $16,51 \mathrm{a}$ & $69,17 d$ \\
\hline
\end{tabular}

Keterangan: Angka yang diikuti huruf yang sama pada kolom yang sama menunjukkan hasil yang tidak berbeda nyata.

Tabel 3 Komponen hasil pada tanaman tomat yang diinfestasi $R$. solanacearum dan tanpa infestasi $R$. solanacearum (Non $\mathrm{RS})$

\begin{tabular}{|c|c|c|c|c|c|c|}
\hline \multirow{3}{*}{ Grup } & \multicolumn{6}{|c|}{ Komponen hasil } \\
\hline & \multicolumn{2}{|c|}{ Jumlah buah/tanaman } & \multicolumn{2}{|c|}{ Bobot buah/tanaman (g) } & \multicolumn{2}{|c|}{ Bobot buah(g) } \\
\hline & $\mathrm{RS}$ & Non RS & $\mathrm{RS}$ & Non RS & RS & Non RS \\
\hline Amelia & $13,80 a$ & $18,10 a b$ & $492,69 a$ & $842,30 \mathrm{bc}$ & $37,36 b$ & $48,72 \mathrm{c}$ \\
\hline H7996 & $31,20 b$ & $40,86 c$ & $765,79 a$ & $1132,71 b c$ & $23,70 a$ & $37,44 b$ \\
\hline Servo & $13,40 a$ & $16,45 a b$ & $557,63 a$ & $851,00 \mathrm{bc}$ & $35,72 b$ & $41,73 b c$ \\
\hline GrftAmlS & $12,30 \mathrm{a}$ & $26,10 \mathrm{abc}$ & $479,92 a$ & $979,40 \mathrm{bc}$ & $35,08 b$ & $46,73 \mathrm{bc}$ \\
\hline GrH7996S & $14,70 \mathrm{a}$ & $44,00 \mathrm{bc}$ & $513,56 a$ & $1440,87 c$ & $35,69 b$ & $41,90 \mathrm{bc}$ \\
\hline
\end{tabular}

Keterangan: Angka yang diikuti huruf yang sama pada kolom yang sama menunjukkan hasil yang tidak berbeda nyata. Kontrol (Amelia, H7996, dan Servo), Penyambungan (GrftAmIS dan GrH7996S). RS = R. solanacearum. 
solanacearum dan tanpa infestasi $R$. solanacearum pada komponen hasil produksi (Tabel 4).

Komponen hasil produksi yang berbeda nyata antara tanaman yang terinfestasi $R$. solanacearum dan yang tidak terinfestasi $R$. solanacearum diduga karena infestasi $R$. solaancearum mengakibatkan kelayuan bahkan kematian tanaman sehingga secara langsung menurunkan komponen hasil produksi. Hal ini sejalan dengan pernyataan Suchoff et al. (2019) yang melaporkan bahwa penggunaan batang bawah di dalam penyambungan menunjukkan adanya peningkatan hasil produksi di dalam kondisi tanpa adanya infeksi $R$. solanacearum. Gilardi et al. (2013) juga menyatakan bahwa tomat sambung mampu meningkatkan vigor tanaman dan hasil produksi ketika tidak ada tekanan penyakit. Infestasi $R$. solanacearum juga menunjukkan adanya pengaruh pada kualitas buah yang meliputi diameter buah, kekerasan buah, dan total padatan terlarut (Tabel 5).

Kualitas buah pada tomat sambung menunjukkan hasil yang tidak berbeda nyata dibandingkan dengan batang atas, namun berbeda nyata dibandingkan dengan batang bawah masing-masing, yaitu di diameter buah dan kekerasan buah. Tomat sambung (GrAmIS) memiliki diameter buah yang berbeda nyata dibandingkan dengan batang bawah (Amelia), sedangkan tomat sambung (GrH7996S) memiliki kekerasan buah yang berbeda dibandingkan dengan batang bawah (H7996). Perbedaan diameter buah dan kekerasan buah antara tomat sambung dan tomat batang bawah diduga dipengaruhi oleh karakteristik varietas tomat yang digunakan. Akan tetapi, pada tomat sambung, kualitas buah lebih dipengaruhi oleh varietas tomat yang digunakan sebagai batang atas. $\mathrm{Hal}$ ini sejalan dengan hasil uji T yang menunjukkan adanya perbedaan yang signifikan di dalam diameter buah dan kekerasan buah (Tabel 6).

Infeksi $R$. solanacearum tidak secara signifikan memengaruhi kandungan total padatan terlarut. Nilai total padatan terlarut antara yang terinfestasi $R$. solanacearum dan tanpa infestai $R$. solanacearum menunjukkan hasil yang tidak berbeda nyata. Nilai total padatan terlarut yang terkandung di tomat sambung, varietas tomat tahan, dan varietas tomat berproduksi tinggi memenuhi persyaratan nilai ${ }^{\circ}$ Brix tomat segar pasar. Nilai ${ }^{\circ}$ Brix tomat segar pasar berkisar antara 3,5-5,3 (Aldrich et al. 2010). Tomat sambung menunjukkan adanya nilai ${ }^{\circ}$ Brix total padatan terlarut yang lebih tinggi dibandingkan dengan tomat batang bawah. Hal ini menunjukkan bahwa dengan penggunaan batang atas yang memiliki sifat agronomi baik di penyambungan mampu meningkatkan nilai total padatan terlarut pada buah. Hal ini sejalan dengan laporan Abdulaziz et al. (2017) yang menyatakan bahwa penyambungan mampu meningkatkan dan memperbaiki kualitas buah.

\section{KESIMPULAN}

Tomat sambung dengan kombinasi varietas tahan sebagai batang bawah dan varietas tomat berproduksi tinggi sebagai batang atas yang terinfestasi $R$. solanacearum secara langsung berpengaruh pada intensitas penyakit layu bakteri, komponen hasil produksi tanaman, dan kualitas buah. Infestasi $R$.

Tabel 4 Komponen hasil produksi tomat sambung yang terinfestasi dan tanpa tanpa infestasi $R$. solanacearum

\begin{tabular}{lcc}
\hline Parameter komponen hasil produksi tanaman & $\mathrm{df}$ & Sig. \\
\hline Jumlah buah/tanaman (RS) - Jumlah buah/tanaman (Non RS) & 49 & .000 \\
Bobot buah/tanaman (RS) - Bobot buah/tanaman (Non RS) & 49 & .000 \\
Bobot/buah (RS) - Bobot/buah (Non RS) & 49 & .000 \\
\hline Keterangan: $\begin{array}{l}\text { sig<0,01 menunjukkan adanya perbedaan yang nyata, RS (infestasi R. solanacearum), Non RS (Tanpa } \\
\text { infestasi R. solanacearum). }\end{array}$
\end{tabular}

Table 5 Kualitas buah tanaman tomat yang terinfestasi $R$. solanacearum (RS) dan tanpa infestasi $R$. solanacearum

\begin{tabular}{|c|c|c|c|c|c|c|}
\hline \multirow{3}{*}{ Grup } & \multicolumn{6}{|c|}{ Kualitas buah } \\
\hline & \multicolumn{2}{|c|}{ Diameter buah (cm) } & \multicolumn{2}{|c|}{ Kekerasan buah } & \multicolumn{2}{|c|}{ Total padatan terlarut ( ${ }^{\circ}$ Brix $)$} \\
\hline & RS & Non RS & RS & Non RS & $\mathrm{RS}$ & Non RS \\
\hline Amelia & $4,59 c$ & $4,93 c$ & $48,78 a$ & $49,34 a$ & $4,61 \mathrm{a}$ & $4,26 a$ \\
\hline $\mathrm{H} 7996$ & $3,31 a$ & $3,22 a$ & $44,32 a$ & $43,75 a$ & $4,53 a$ & $4,28 \mathrm{a}$ \\
\hline Servo & $3,79 b$ & $3,81 b$ & $59,51 b$ & $53,09 b$ & $4,98 \mathrm{a}$ & $4,45 a$ \\
\hline GrfAmIS & $3,59 a b$ & $3,75 b$ & $51,66 a b$ & $55,67 \mathrm{~b}$ & $4,66 \mathrm{a}$ & $4,43 a$ \\
\hline GrH7996S & $3,51 \mathrm{ab}$ & $3,53 a b$ & $58,07 \mathrm{~b}$ & $58,23 b$ & $4,61 \mathrm{a}$ & $4,42 a$ \\
\hline
\end{tabular}

Keterangan: Angka yang diikuti huruf yang sama pada kolom dan baris yang sama menunjukkan hasil yang tidak berbeda nyata. Varietas tomat tahan (Amelia, H7996), varietas tomat berproduksi tinggi (Servo), tomat sambung (GrftAmIS GrH7996S), RS (infestasi R. solaancearum), Non RS (tanpa infestasi R. solaancearum).

Tabel 6 Komponen kualitas buah pada tomat sambung yang terinfestasi (RS) dan tanpa infestasi $R$. solanacearum (Non RS)

\begin{tabular}{lll}
\hline Pasangan parameter kualitas buah & df & Sig. \\
\hline Kekerasan Buah (RS) - Kekerasan Buah (Non RS) & 99 & .000 \\
Total padatan terlarut (RS) - Total padatan terlarut (Non RS) & 99 & .198 \\
Diameter buah (RS) - Diameter buah (Non RS) & 49 & .001 \\
\hline
\end{tabular}

Keterangan: sig<0,01 menunjukkan adanya perbedaan yang signifikan. 
solanacearum memengaruhi intensitas penyakit layu bakteri pada tomat sambung yang tidak berbeda nyata dibandingkan dengan batang bawah tahan, namun berbeda nyata dibandingkan dengan batang atas. Infestasi $R$. solanacearum pada tomat sambung mampu menurunkan produktivitas tanaman yang mengakibatkan rendahnya komponen hasil produksi. Selain itu, adanya infeksi $R$. solanacearum juga menurunkan kualitas buah, yaitu diameter dan kekerasan buah, namun tidak berpengaruh pada nilai ( ${ }^{0}$ brix) total padatan terlarut (TTS) buah. Akan tetapi, nilai ( ${ }^{\circ}$ brix) TTS pada tomat sambung menunjukkan nilai yang lebih tinggi dibandingkan dengan batang bawah tahan yang terinfestasi dan tidak terinfestasi $R$. solanacearum.

\section{UCAPAN TERIMA KASIH}

Ucapan terima kasih disampaikan kepada Kementerian Pertanian sebagai sponsor pemberi beasisawa pendidikan dan LPDP atas bantuan pembiayaan penelitian ini.

\section{DAFTAR PUSTAKA}

Abdulaziz AH, Abdulrasoul AO, Thabet A, Hesham AR, Khadejah A, Saad M, Abdullah O. 2017. Tomato grafting impacts on yield and fruit quality under water stress conditions. Journal of Experimental Biology and Agricultural Sciences. 5: S136-S147. https://doi.org/10.18006/2017.5(Spl-1SAFSAW).S136.S147

Aldrich HT, Salandanan K, Kendall P, Bunning M, Stonaker F, Külen O, Stushnoff C. 2010. Cultivar choice provides options for local production of organic and conventionally produced tomatoes with higher quality and antioxidant content. Journal of the Science of Food and Agriculture. 90: 2548-2555. https://doi.org/10.1002/jsfa.4116

Arwiyanto T, Sudarmadi, Hartana. 1996. Deteksi Strain Pseudomonas solanacearum Penghasil Bakteriosin. Jurnal Perlindungan Tanaman Indonesia. 2(2): 60-65.

Arwiyanto T, Nurcahyanti SD, Indradewa D, Widada J. 2015. Grafting local commercial tomato cultivar with H7996 and Eg 203 to suppress bacterial wilt (Ralstonia solanacearum) in Indonesia. Proc.IVth IS on Tomato Disease. Act Hort. 1069: 173-178. https://doi.org/10.17660/ActaHortic.2015.1069.24

AVRDC. 2013. An impact assessment of AVRDC's tomat grafting in Vietnam. AVRDC Publication. 13:773. ISBN 92-9058-203-0

Caldwell D, Kim BS, lyer-Pascuzzi AS. 2017. Ralstonia solanacearum differentially colonizes roots of resistant and susceptible tomato plants.
Phytopathology. 107: 528-536. https://doi.org/ 10.1094/PHYTO-09-16-0353-R

Davis AR, Perkins-Veazie P, Hassell R, Levi A, King SR, Zhang X. 2008.Grafting effects on vegetable quality. Hort.Science. 43: 1670-1672. https:// doi.org/10.21273/HORTSCI.43.6.1670

East west. 2019. Deskripsi varietas tomat Servo. Jakarta (ID).

Genin S. 2010. Molecular traits controlling host range and adaptation to plants in Ralstonia solanacearum. New Phytologist. 187: 920-928. https:// doi.org/10.1111/j.1469-8137.2010.03397.x

Gilardi G, Gullino ML, Garibaldi A. 2013. Critical aspects of grafting as a possible strategy to manage soil-borne pathogens. Scientia horticulturae. 149: 19-21. https://doi.org/10.1016/j.scienta.2012.07. 014

Hanson PM, Wang JF, Licardo O, Mah SY, Hartman GL, Lin YC. 1996. Variabe reaction of tomato line to bacterial wilt evaluated at several location in southeast Asia. HortSciene. 31: 143-146. https:// doi.org/10.21273/HORTSCI.31.1.143

Hariadi, Bambang SP, Djumali, Muhammad C. 2012. Pemilihan Batang bawah dan Teknik penyambungan tanaman jarak pagar (Jatropha curcas)untuk meningkatkan potensi produktifitas $>10$ ton/ha dan tahan terhadap cekaman kekeringan dalam upaya mendukung pengembangan bioenergi. Jurnal Ilmu Pertanian Indonesia. 17(3): 1-10.

Kalpage M, De Costa D. 2014. Isolation of bacteriophages and determination of their efficiency in controlling Ralstonia solanacearum causing bacterial wilt of tomato. Tropical Agricultural Research. 26: 140-151. https://doi.org/ 10.4038/tar.v26i1.8079

Laeshita P, Arwiyanto T. 2017. Resistance Test of Several Tomato Varieties to Bacterial Wilt Diseases Caused by Ralstonia solanacearum. Jurnal Perlindungan Tanaman Indonesia. 21: 51-53.

Louws FJ, Rivard CL, Kubota C. 2010. Grafting fruiting vegetables to manage soilborne pathogens, foliar pathogens, arthropods and weeds. Scientia Horticulturae. 127: 127-146. https://doi.org/ 10.1016/j.scienta.2010.09.023

McAvoy T, Freeman JH, Rideout SL, Olson SM, Paret ML. 2012. Evaluation of grafting using hybrid rootstocks for management of bacterial wilt in field tomato production. Hort.Science 47: 621-625. https://doi.org/10.21273/HORTSCI.47.5.621

Navitasari L, Joko T, Murti RH, Arwiyanto T. 2020. Rhizobacterial community structure in grafted tomato plants infected by Ralstonia solanacearum. 
Biodiversitas. 21(10): 4488-4495. https://doi.org/ 10.13057/biodiv/d211055

Nie L, Chen H, Zhang X, Di B. 2010. Photosynthetic ability dan mineral concentrations in xylem exudate of grafted dan non-grafted watermelon seedlings. Acta horticulturae. 319. https://doi.org/ 10.17660/ActaHortic.2010.871.43

Poudel R, Jumpponen A, Kennelly MM, Rivard CL, Gomez-Montano L, Garrett KA. 2019. Rootstocks Shape the Rhizobiome: Rizosfir dan Endosphere Bacterial Communities in the Grafted Tomato System. Applied and Environmental Microbiology. 85. https://doi.org/10.1128/AEM.01765-18

Schwarz D, Daniella B, Giuseppa C, Youssef R, Mariateresa C, Elvira R. 2012. Effect of Nitrogen form dan nutrient solution $\mathrm{pH}$ on growth dan mineral composition of self-grafted dan grafted tomatoes.
Scientia Horticulturae. 149: 61-69. https://d oi.org/10.1016/j.scienta.2012.02.012

Scott J, Wang J, Hanson P. 2004. Breeding tomatoes for resistance to bacterial wilt, a global view, I International Symposium on Tomato Diseases 695. pp. 161-172. https://doi.org/10.17660/ActaHortic. 2005.695.18

Suchoff D, Gunter C, Schultheis J, Louws F. 2014. Onfarm grafted tomato trial to manage bacterial wilt, I International Symposium on Vegetable Grafting 1086. pp. 119-127. https://doi.org/ 10.17660/ActaHortic.2015.1086.14

Suchoff DH, Louws FJ, Gunter CC. 2019. Yield and disease resistance for three bacterial wilt-resistant tomato rootstocks. Horttechnology. 29: 330-337. https://doi.org/10.21273/HORTTECH04318-19 